\section{LAW AND POLITICAL \\ SCIENCE SECTION}

Vice-Chairman/Chairman-Elect

Oleg Kudryk, Head, Acquisitions Department, Indiana University Libraries, Bloomington, Indiana

Catherine A. Porter, Librarian, Vinson, Elkins, Searls, Connally \& Smith (Attorneys at Law ), Houston, Texas

Member-at-Large

To be nominated

\section{RARE BOOKS AND MANUSCRIPTS SECTION}

Vice-Chairman/Chairman-Elect

J. William Matheson, Chief Librarian, Rare Book Division, Library of Congress, Washington, D.C.

Clyde C. Walton, Director of Libraries, Northern Illinois University, DeKalb, Illinois

Secretary

Shirley B. Lebo, Principal Evaluations Officer, Library of Congress, Washington, D.C.

N. Frederick Nash, Rare Book Room Librarian, University of Illinois, Urbana, Illinois

Member-at-Large

Vesta Lee Gordon, Assistant Curator for Technical Services, Manuscripts Department, Alderman Library, University of Virginia, Charlottesville, Virginia

J. Richard Phillips, Special Collections Li- brarian, Amherst College, Amherst, Massachusetts

\section{SLAVIC AND \\ EAST EUROPEAN SECTION}

Vice-Chairman/Chairman-Elect

George C. Jerkovich, Head, Slavic Department, University of Kansas Libraries, Lawrence, Kansas

Oleg Kudryk, Head, Acquisitions Department, Indiana University Libraries, Bloomington, Indiana

Secretary

Christopher J. Guleff, Special Services Librarian, Indiana State University, Terre Haute, Indiana

Benedict Markowski, Head, Foreign Language Collection, Detroit Public Library, Detroit, Michigan

Member-at-Large

Gordana Rezab, Assistant Acquisitions Librarian, Western Illinois University, Macomb, Illinois

Eryk Talat-Kielpsz, Senior Slavic Cataloger, Ohio State University Library, Columbus, Ohio

\section{UNIVERSITY LIBRARIES SECTION}

Vice-Chairman/Chairman-Elect

C. James Schmidt, Director of Libraries, State University of New York at Albany, Albany, New York

James K. Zink, Director of Libraries, University of Oklahoma, Norman, Oklahoma

\title{
ACRL Chapter News
}

The Illinois Association of College and Research Libraries at its fall meeting, October 25, 1974, in Springfield, announced the results of its recent elections. Officers of the chapter for 1974/75 are: Clyde C. Walton, director of libraries at Northern Illinois University, DeKalb, chairman; Imogene I. Book, librarian at Rend Lake College, Ina, vice-chairman; and Robert $\mathrm{N}$. Broadus, professor of library science at

\section{SLIP.ON BOOK JACKETS \\ OF CLEAR PLASTIC BOOK PAL。 \\ pal enterprises \\ 4646 gravois \\ st. louis, mo. 63116 \\ (314) $481-2779$}

Protective

Attractive

Long-lasting
Northern Illinois University, secretary. The editor of the chapter's new publication, the IACRL Newsletter, is Herbert Biblo, head of reader services at the John Crerar Library.

ACRL's Minnesota chapter, the Academic and Research Division of the Minnesota Library Association, has also announced new officers for 1974/75: Virgil F. Massman, executive director of the James J. Hill Reference Library, St. Paul, chairman; Rosalie Bunge, librarian at Normandale Community College, Bloomington, chairman-elect; and Karen Fischer, librarian at the College of St. Benedict, St. Joseph, secretary/treasurer. Lawrence R. Cullen, librarian at North Hennepin Community College, Minneapolis, is serving as editor for the chapter and is responsible for submitting news items for publication in the Minnesota Library Association newsletter and journal. 